\title{
Recitation of the Succession of the Sunan Kudus in Cultural Da'wa
}

\author{
Bekti Taufiq Ari Nugroho ${ }^{1^{*}}$, Choeroni ${ }^{2}$, M. Minanur Rohman ${ }^{3}$ \\ 1. Postgraduate Program at Walisongo Islamic University, Semarang, Indonesia \\ ${ }^{2}$ Sultan Agung Islamic University, Semarang, Indonesia \\ ${ }^{3}$ State Institute for Islamic Studies Pekalongan, Indonesia \\ *Corespending author: ${ }^{1 *}$ bektitaufiq65@gmail.com, ${ }^{2}$ choer.indab@gmail.com, \\ 3m.minanur.robman@iainpekalongan.ac.id
}

\begin{abstract}
Wali comes from Wala or Waliya which means close, has a role in continuing the prophetic mission. In the Quran, this term is used to mean a relative, friend or protector. In carrying out the role of continuing the mission of prophecy, the saints who are more familiarly called Walisongo always invite Islam and Ahl al-Sunnah Wa al-Jama'ah, the da'wa used by Walisongo in realizing its mission is the application of the methods developed by Sunni Sufis in imparting teachings. However, the methods of preaching that are carried out by the saints are different, the values of pluralism as practiced by Sunan Kudus are very different from other saints, where Sunan Kudus used methods by utilizing traditional symbols and beliefs of the local community, evidence of Da'wa methods are still visible today, namely the shape and style of the building of the al-Aqsa mosque, minarets, gates, and showers (ablution places) which are actually symbols of the eight Buddhist paths, each of which is given a statue of the head of Kebo Gumarang as a permanent Buddhist teaching. preserved as part of cultural assimilation.
\end{abstract}

Keywords: Culture; Da'wa; Guardian ; Sunan Kudus; Symbol

\section{Introduction}

Sunan Kudus in Islamic preaching is full of cultural approaches, this is evident in the holy tower which contains assimilation of Hindu, Buddhist, Chinese and 
Islamic cultures. ${ }^{1}$ Symbols seen from the architecture of the Mosque Kudus, minarets, gates and showers on ablution which symbolize the eight Buddhist paths as a form of compromise made by the Sunan Kudus. In teaching Islam, Sunan Kudus emphasizes the importance of tolerance in social life, that life must be balanced between manners, behavior, work and worship.

Here there are elements that mix up one another so that they all become one. ${ }^{2}$ In architecture, the term syncretism can be interpreted as a combination of various styles in architecture, which are related to religious activities, traditions, cultural practices, foreign elements (foreign), and colonialism. ${ }^{3}$

The concept of mixing architectural forms associated with elements of physical culture cannot be traced by the approach of architectural science. Acculturation occurs when groups of individuals who have different cultures deal with each other directly intensively, and for a long time, with the emergence of major changes in the cultural pattern of one or both of the cultures concerned. ${ }^{4}$ In the acculturation process, there are four strategies, namely the process of assimilation, separation, integration, and marginalization.

Assimilation occurs when individuals do not wish to maintain their cultural identity and seek daily interactions with other cultures. Here individuals prefer to shed their cultural heritage, and become absorbed into the dominant society. Separation occurs when individuals place value on their native culture, and at the same time want to avoid interacting with other people. Integration occurs when individuals are still strong in maintaining their cultural heritage, and at the same time have daily interactions with other groups. Thus marginalization occurs when individuals have little interest in maintaining cultural heritage, and at the same time having little interest in associating with other groups. ${ }^{5}$

Acculturation, the attitude of the local community towards foreign civilization occurs in three circumstances. First, if local civilization is weak, then what will happen is adoption, that is, a position that is always dictated by a stronger civilization. Second, if the local civilization is strong against a weak external civilization, then adaptation will occur. Third, if local and foreign

1 Nh Dini, Dari Ngalian ke Sendowo, Jakarta: Gramedia Pustaka Utama, 2015, hlm. 77

2 Irina A Levinskaya (1993), "Syncretism - The Term and Phenomenon,"Tyndale Bulletin. $44.1 \mathrm{hlm}$. 117-128.

3 Asif Ali (2013), “Syncretic Architecture of Fatehpur Sikri: A Symbol of Composite Culture,” Journal of Islamic Architecture, Volume 2 Issue 3 June 2013, hlm.101-105.

4 Ali, Syncretic..hlm. 90

5 Levinskaya, "Syncretism hlm. 80 
civilizations are equally strong, there will be synergy, meaning that they provide equal input. ${ }^{6}$

\section{Methods}

This study uses a qualitative method with an ethnographic approach. The determination of informants is not based on the number of informants in the field. Researchers describe a fact based on direct visions and historical facts. The determination of informants is also not determined by the quantity, but the main thing is to describe it based on the findings. As was done by Clifford Geertz, known as thick description. ${ }^{7}$ Ethnographic research can be assumed, so that general knowledge is obtained systematically, but can be interpreted based on the aspects of the study of ontology (existence), epistemology (philosophy of origin) and axiology (appearance). This is used to see how the succession of cultural da'wah was carried out by Raden Ja'far Shodiq as Sunan Kudus.

\section{Result and Discussion}

\subsection{Bibliography of Sunan Kudus}

Raden Jafar Sadiq or better known as Sunan Kudus, is the son of Raden Usman Haji who has the title Sunan Ngudung in Jipang Panolan (some say it is north of the Blora), Sunan Ngudung is a Demak senopati who died in battle against Duke of Eggplant from Majapahit (after making peace with Demak, the Duke of eggplant converted to Islam and had the title Raden Husain, he was finally known to be the older brother of Raden Fatah). The order of the lineage of Sunan Kudus is the $24^{\text {th }}$ descendant of the Prophet Muhammad (Peace be upon Him) through the lineage of Al-Husain bin Sayyidah Fatima Az-Zahra bint Prophet Muhammad. ${ }^{8}$

When he continued his descendants, Sunan Kudus married the daughter of Raden Maqdum Ibrahim or Sunan Bonang from Tuban named Dewi Rukhil. From this marriage Sunan Kudus was awarded a son named Amir Hasan. In addition, Sunan Kudus also married the daughter of the prince Pecat Tandaterung from Majapahit who gave birth to eight sons, namely; 1. Nyi Ageng Pambayun, 2. Panembahan Palembang, 3. Panembahan Mekaos Honggokusumo,

6 Purnama Salura, Sebuah Kritik, Arsitektur Yang Membodobkean, Jakarta: Gakushudo, hlm. 25

7 Suwardi Endaswara, Metodologi Penelitian Kebudayaan, Yogyakarta: Gadjah Mada University Press, 2006, hlm. 53

8 Shohibul Faroji, Ensiklopedi Nasab Imam Al-Husain. Penerbit Walisongo Center, 2011, hlm. 30. 
4. Panembahan Qodhi, 5. Panembahan Karimun, 6. Panembahan Joko, 7. Ratu Pakojo, 8. Ratu Prodobinabar, who finally married his warlord named Prince Poncowati, of his sons and daughters, only four have been detected, namely; 1 . Panembahan Palembang, 2. Panembahan Joko, 3. Pangeran Poncowati, and 4, Panembahan Mekaos Honggokusumo. ${ }^{9}$

Sunan Kudus is known as Alim, who has extensive knowledge, including the knowledge of Jurisprudence, Ushul Fiqh, Tafsir, and Mantiq, because of the depth of knowledge, Sunan Kudus is called the "big teacher" with the title Waliyyul 'Ilmi, because of his wisdom. There were many students who came from various regions to learn from him, they were next as cadres and students of the militant Sunan Kudus. Some of them even served and participated in the struggle until they died, such as; Kyai Daulat, Kyai Mijil, whose grave is adjacent to the tomb of Sunan Kudus.

As a sufism, and commander of the Walisongo who views that educating is a duty and a religious calling, educating students and students is the same as educating one's own biological children. Thus, the concept developed by Sunan Kudus in educating his students is education that is imbued with high sincerity and is oriented towards self-transformation that is in favor of Islamic values, which has a true and directed life vision based on Islam, or make Islam on his way of life. ${ }^{10}$

Sunan Kudus is known as a resilient merchant, we can understand that because in carrying out his missionary mission, it cannot be separated from local or international networks. So it is understandable, why Islam is easy to develop in coastal areas, including in Kudus. In the 15th century, several Muslim merchants had made progress both in business and in their preaching. This is also inseparable from the pioneering work of Sunan Kudus, especially its role in the Kudus, Demak and Jepara areas, so that now we know Kudus as the industrial city, Jepara is known for its carving products and Demak as a large fish-producing city. ${ }^{11}$

The da'wa carried out by Sunan Kudus is closer to the method practiced by Sunan Kalijaga who has a tolerant attitude and wisdom towards local culture and Sunan Kudus was a role model for the seasons on the north coast of Java. ${ }^{12}$ Among the preaching of Sunan Kudus like: (1) Letting go of old customs and

9 Nur Said, Jejak Perjuangan Sunan Kudus dalam Membangun karakter Bangsa, Bandung: Brillian Media Utama, 2010, hlm. 31.

10 Nur Said, Jejak Perjuangan Sunan Kudus dalam Membangun karakter Bangsa, ..., hlm. 37-38.

11 Nur Said, Jejak Perjuangan Sunan Kudus dalam Membangun karakter Bangsa, ..., hlm. 39.

12 A. Mustofa Bisri, Koridor; Renungan A. Mustofa Bisri, Jakarta: Buku Kompas, 2010, hlm. 47. 
beliefs that are difficult to change; (2) Through to get closer to the people and their traditions by filling in Islamic nuances, he even had advantages compared to Sunan Kalijaga, namely his refinement of nature and prudence, because of these advantages, the walisongo asked him to preach in the Holy area whose people still adhere to it. steadfast in his religious beliefs, namely Hindu-Buddhist; (3) The philosophy Tut Wuri Handayani as the principle in teaching Islam from behind; (4) Avoid direct or violent confrontation in broadcasting Islam; (5) It is permissible to change the customs and beliefs of the community that are not in accordance with Islamic teachings, but on the principle of not driving the community away from Muslims. ${ }^{13}$

Indeed, the basic principle of the Walisongo da'wa is based on theory "hikmah or wisdom" as in the Quran said:

"Call (humans) to the way of your Lord with wisdom and good lessons and argue with them in a good way. Indeed it is your Lord He who knows better about who has strayed from His ways and He who knows better those who are guided."(QS. al-Nahl (16): 125).

Sunan Kudus applies "al-Hikmah" in his preaching, so that people who previously embraced Hinduism gradually embraced Islam in a sympathetic, peaceful and far from violence. ${ }^{14}$ The strategy of Sunan Kudus was obtained from Chinese culture through his teacher who came from mainland China, namely Kyai Telingsing as the Ling Shing, a scholar from China who came to Java Dwipa with General Cheng Hoo. ${ }^{15}$

\subsection{The Value of Cultural Da'wa Pluralism of Sunan Kudus and the analysis of the interpretation of the Kudus Mosque}

Pluralism in the social sciences, pluralsm is a framewrk of interaction in wich groups show sufficient respect and tolerance of each other, that they fruitfully coexist and interact without conflict or assimilation. ${ }^{16}$ The da'wa strategy of Sunan Kudus is actually the same as that of Sunan Kalijaga, Sunan Bonang and other Sunan, Sunan Kudus da'wa model emphasizes pluralism that uses a cultural approach that can be observed in the following phenomena:

13 Rizem Aizid, Sejarah Islam Nusantara; Dari Analisis Historis Hingga Arkeologis tentang Penyebaran Islam di Nusantara, Yogyakarta: DIVA Press, 2016, hlm. 185.

14 Nur Said, Jejak Perjuangan Sunan Kudus dalam Membangun karakter Bangsa, ..., hlm. 67.

15 Wawan Susatya, Senyum Manis Wali Songo, Jogjakarta: Diva Press, 2009, hlm. 307.

16 Rodiah, dkk, Studi Alquran Metodedan Konsep, Yogyakarta: eLSAQPress, 2010, hlm. 335. 


\subsubsection{Making a Cultural Sphere}

As was done by Rasulullah in fostering the people of Medina, namely building the Quba mosque, this was also done by Sunan Kudus in developing his preaching in Kudus. He founded a mosque known as the Nganguk Wali Mosque, after his preaching became more established, Sunan Kudus built a large mosque called Masjid al-Aqsa equipped with a beautiful minaret.

Menara Kudus when viewed from an architectural point of view, its shape resembles a temple building in Bali or Candi Jago, a Hindu-Buddhist heritage in Malang. ${ }^{17}$ The ornaments that are on the Kudus tower also reflect cross-cultural such as the plate attached to the tower wall is a model of a Chinese dish.

The existence of the al-Aqsa mosque and the Kudus Menera which stand firmly, upright and towering above is a sign that the old belief building, namely Hinduism, will soon be abandoned and turn to a new belief, namely Islam. But in its succession, it does not necessarily eliminate the old belief symbols, this is evidenced by the construction of mosques and minarets that still pay attention to and respect the patterns and forms of buildings that previously existed, which are similar to pure as a place of worship for the Buddhist community. ${ }^{18}$

The presence of the Kudus tower also indicates the existence of Islam in Kudus, a new era in which Islam is beginning to be accepted by the public. Besides that, the Menara Masjid Kudus also marks the spirit of Sunan Kudus to expand the formation of Islamic cultural spaces in other areas. So if now the Kudus community is familiar with the term "Wali Mosque", actually it is an expression of Sunan Kudus in widening and expanding the cultural space where Islam is the basis of values in all its movements and steps, then in Kudus there will be many guardian mosques such as; the Madureksan wali mosque which is said to have been the meeting place for the wali in Kudus, the Japanese guardian mosque and the Hadiwarno mosque in Mejobo district; Wali Loram mosque, and many other wali mosques in Kudus as a recitation of Sunan Kudus preaching in the area. As in the time of the Prophet Muhammad, the mosque was not only used as a place for ritual and mahdhah worship only, in the mosque also the guardians devised strategies to lift people from ignorance and adversity, carry out recitation and education associations and deliberation of other activities for the benefit of the Ummah. The mosque has also become the forerunner to the growth of the seeds of the pesantren which became a cultural space after the mosque, and

17 Rizem Aizid, Sejarah Islam Nusantara; Dari Analisis Historis Hingga Arkeologis tentang Penyebaran Islam di Nusantara, ..., hlm. 186.

18 Nur Said, Jejak Perjuangan Sunan Kudus dalam Membangun karakter Bangsa, ..., hlm. 69. 
from the pesantren the network of guardians and ulama began to be very strong. Through this network, Walisongo's footsteps began to step into power so that the Islamic empire was created. This situation facilitated the preaching of Islam which previously only relied on a cultural approach, starting a new phase, namely a structural approach, such as the existence of the Demak sultanate, the Cirebon sultanate, however, the cultural approach is still maintained. ${ }^{19}$

\subsubsection{Acculturation}

In preaching in the community, Sunan Kudus uses methods by utilizing the symbols of their traditions and beliefs, evidence of this da'wah method is still visible today, namely the shape and style of the al-Aqsa mosque building, minarets, gates, and the form of a shower (a place to take ablution water ) which is actually a symbol of the eight Buddhist paths, each of which is given a statue of the head of a Kebo Gumarang on it, this implies like the Buddha's teachings, namely Asta Sanghika Marga (the eightfold path), that is to have correct knowledge, make the right decisions, speak the truth, live the right way, work properly, worship properly, live religion properly, and practice it properly. ${ }^{20}$

It was also told that one day Sunan Kudus hoped that many people would come to the mosque to receive his preaching, the way Sunan Kudus did was somewhat strange, namely by tethering a cow of his named Kebo Gumarang in the courtyard of the Mosque. Sunan Kudus raised questions in the hearts of the Kudus community, so many of them immediately came to see what Sunan Kudus would do with the Cow. When the people began to come, Sunan Kudus advised them not to slaughter cows, he argued that he had fond memories of a cow. In his childhood, he almost died of thirst, but suddenly there was a cow who fed him so that he was saved. Hearing the explanation from Sunan Kudus, the Kudus community began to gain more confidence in him, even some of them thought that Sunan Kudus was an incarnation of Lord Vishnu who manifested on the face of the earth. Since then, the Kudus community began to frequently come to Sunan Kudus house because of their curiosity.

Then when more and more people came, the Holy Sunan began to mention the Holy book of the Koran, Sunan Kudus told them "Know that in the Koran, the holy book of the Islamic ummah there is a letter al-Baqarah. which means

19 Nur Said, Jejak Perjuangan Sunan Kudus dalam Membangun karakter Bangsa, .., hlm. 71.

20 Wawan Susatya, Senyum Manis Wali Songo, ..., hlm. 311. 
female cow. In fact, every day, I and the Muslims always read it. ${ }^{21}$ Sunan Kudus was to attract the hearts and sympathy of the people, because he knew that Cows are animals that are considered sacred among Buddhists. From the explanation and method of preaching carried out by Sunan Kudus, the Kudus community became more sympathetic and followed the preaching of Sunan Kudus. Finally, the Kudus community, which was originally a Hindu-Buddhist majority, flocked to following the preaching of Sunan Kudus and claiming to convert to Islam.

Besides that, Sunan Kudus conveyed it in a heart-binding way, namely by composing religious stories, among his famous works were Gending masumambang and mijil, because besides being a deep knowledge of his religion Sunan Kudus was also known as a poet and folklore composer, which has the vision of monotheism. ${ }^{22}$ This is clear evidence that the success of the preaching carried out by Sunan Kudus uses the traditional approach of the local community and does not necessarily reject the community's traditions but by keeping them with Islamic values. Because of the complaints of the Kudus community to the sunan, until now there has been no cow slaughtering in this city, every religious ceremony or anything else, the cow is usually replaced by a buffalo and other halal animals. ${ }^{23}$

In conveying his preaching, Sunan Kudus did not oppose frontally the customs of their ancestors, but rather directed it into a more Islamic form, for example, salvation events, for example selametan neloni, mitoni, or customs after someone died, such as the third, seventh day ceremony, , forty, etc., which originally sent offerings to the gods, by the Holy Suna directed with the intention of giving alms to the community, on such occasions, Sunan Kudus led by directing requests directly to God as well as leading his prayers. ${ }^{24}$

\subsubsection{Disease Treatment}

Sunan Kudus is an expert in the field of medicine, it is said that when Sunan Kudus performed the pilgrimage and lived temporarily there, the opportunity was used to study at Baitul Maqdis. When he was in the city, the people there were stricken with disease and no healer was able to find a cure, Sunan Kudus was able to eradicate the disease that hit the inhabitants of the Palestinian city.

21 Wawan Susatya, Senyum Manis Wali Songo, ..., hlm. 310.

22 M. Fauzi, Kisah Teladan wali Songo, Jogjakarta: Tera Insani, 2007, hlm. 43.

23 M. Fauzi, Kisah Teladan wali Songo, ..., hlm. 41.

24 Nur Said, Jejak Perjuangan Sunan Kudus dalam Membangun karakter Bangsa, ..., hlm. 311. 
Because of his services, Sunan Kudus was given a gift of territorial power in the Palestinian territories, but Sunan Kudus refused because he did it with sincere intentions because Allah the Almighty was to help others and he chose to return to Java. Before returning home, he only asked for a memento of a stone which would later be used as a memorial to the construction of the Menara Kudus mosque. After returning from studying in Palestine, in 1549 AD, Sunan Kudus built a mosque which was named Masjid al-Aqsa or Manara (Menara Kudus), from which the name of the mosque was the origin of the name of the city of Kudus, namely the name introduced by Sunan Kudus in reference to the name a city in Palestine. ${ }^{25}$ Expertise in the field of medicine is also used by Sunan Kudus to strengthen his means of preaching in spreading Islam in Kudus and its surroundings.

The spread of Islam in Indonesia, especially in Java, there are legends that link the spread of Islam with the epidemic that hit the population, traditions about Islamic conversion are related to the belief that Islamic figures are good at healing. In addition, Islam also offers salvation from various evil forces, for example, people who are obedient and pious will be protected by Allah from every spirit and evil force, and they will even be rewarded with a heaven in the afterlife. Likewise, people who are miserable will get the same reward if they do good deeds. ${ }^{26}$ This erodes the old view that the afterlife is full of frightening possibilities, whereas Islam introduces the promise of a pleasant heaven. So treatment is a powerful means of giving sympathy to the people about Islam, which causes them to flock to declare themselves to embrace Islam.

\subsubsection{Exemplary}

Exemplary or modeling is the way people learn by imitating and observing the behavior of others, namely by choosing a model so as to produce information that the person concerned is systematically imitating the more dominant model. In this case, Sunan Kudus has positioned himself as a personal figure who appears as an exemplary figure, starting from creativity in work, tolerance in culture, networks in preaching and his loyalty to science.

Through this exemplary process, Sunan Kudus is positioned very respectfully in the social structure in Kudus, and with the success of this example, Sunan

25 M. Fauzi, Kisah Teladan wali Songo, ..., hlm. 41.

26 Sunanto \&Musyrifah, Sejarah Peradaban Islam di Indonesia, Jakarta: PT. Raja Grafindo Persada, 2010, hlm. 21. 
Kudus becomes a place of escape for every society that is having problems, whether personal, family, social, political or even economic problems. ${ }^{27}$

\subsubsection{Build Networking}

Walisongo is a number of Islamic preachers who prioritize communication with others. They are a kind of institutional guardian council in which Sunan Kudus is in it, so that he is the pioneer of a solid and well-communicated Islamic da'wa network, among them face big problems that cannot be resolved personally, they do not hesitate to conduct joint deliberations to find the best solution, usually the meeting is held at the Bintoro Demak mosque. Many cases have been resolved in this way, including solving the cases of Sheikh Siti Jenar, Ki Ageng Pengging, and so on.

With a system like this, walisongo has succeeded in developing da'wah not only in Java but also throughout the archipelago. Thus, the system and strategy of walisongo da'wah in general and Sunan Kudus in particular was an extraordinary achievement and surpassed the progress of its era. ${ }^{28}$

\section{Conclusion}

The hermeneutic approach in culture has understood to go beyond textual interpretation. Therefore hermeneutics has fundamental to all humanities, because all of these disciplines use the interpretation of human works. Through the study of hermeneutical theory, the humanities can achieve a full assessment of self-knowledge and a better understanding of the nature of the humanities task.

Global ethics expert named Hans Kung emphasized that in the postmodern era the ethical needs that are longed for in multicultural social institutions are: not only freedom but also justice, not just equality but also plurality, not just brotherhood between men but also between women, not just life side by side but also live in peace, not only productive but also caring for the environment, not only tolerance but also interfaith cooperation to overcome human problems. It turns out that the global ethics as offered by Hans Kung, have been implemented by Walisongo since 5 centuries ago when spreading Islam in Java, especially Sunan Kudus which is very thick with aspects of cultural acculturation, needs a material

$\begin{array}{ll}27 & \text { Nur Said, Jejak Perjuangan Sunan Kudus dalam Membangun karakter Bangsa, ..., hlm. } 79 . \\ 28 & \text { Nur Said, Jejak Perjuangan Sunan Kudus dalam Membangun karakter Bangsa, ..., hlm. } 81 .\end{array}$ 
for reflection for Muslims who live in the present era to organize cross-cultural and religious life that is colored with a culture of peace and social solidarity as practiced by the walisongo, especially by Sunan Kudus and Walisongo.

\section{Reference:}

Aizid, Rizem. Sejarab Islam Nusantara; Dari Analisis Historis Hingga Arkeologis tentang Penyebaran Islam di Nusantara, Yogyakarta: DIVA Press, 2016.

Amin, Samsul Munir. Sejarah Peradaban Islam, Jakarta: Amzah, 2010.

Asif Ali. "Syncretic Architecture of Fatehpur Sikri: A Symbol of Composite Culture," Journal of Islamic Architecture, Volume 2 Issue 3 (2013).

Bisri, A. Mustofa. Koridor; Renungan A. Mustofa Bisri, Jakarta: Buku Kompas, 2010.

Dini, Nh. Dari Ngalian ke Sendowo, Jakarta: Gramedia Pustaka Utama, 2015.

Faroji, Shohibul. Ensiklopedi Nasab Imam Al-Husain. Penerbit Walisongo Center, 2011.

Fauzi, M. Kisah Teladan wali Songo, Jogjakarta: Tera Insani, 2007.

Indrahti, Sri. Kudus dan Islam: Nilai-Nilai Budaya Lokal dan Industri Wisata Ziarah, Semarang: CV Madina, 2012.

Irina A Levinskaya, “Syncretism-The Term and Phenomenon,”Tyndale Bulletin, (1993): 117-128.

Palmer. Hermeneutika, Teori Baru Mengenai Interpretasi. Yogyakarta: Pustaka Pelajar, 2003.

Purnama Salura. Sebuah Kritik Arsitektur Yang Membodobkan, Jakarta: Gakushudo, 2015.

Rahimsyah. Kisah Walisongo; Para Penyebar Agama Islam di tanah Jawa, Surabaya: Mulia jaya, 2008.

Rodiah, dkk. Studi Alquran Metodedan Konsep, Yogyakarta: eLSAQPress, 2010.

Said, Nur. Jejak Perjuangan Sunan Kudus dalam Membangun karakter Bangsa, Bandung: Brillian Media Utama, 2010.

Sunanto \& Musyrifah. Sejarah Peradaban Islam di Indonesia, Jakarta: Raja Grafindo Persada, 2010.

Susatya, Wawan. Senyum Manis Wali Songo, Jogjakarta: Diva Press, 2009. 